\title{
Experimental Study of Heat Transfer Rate in Single and Series Cross Flow Heat Exchanger using Matlab Coding
}

\author{
P.ParabrahmaSai, K.Lakshmi Prasad, P.Ravindra Kumar, K. Srinivasa Rao
}

\begin{abstract}
The present study investigates the heat transfer rate and effectiveness of cross flow heat exchanger by varying velocity and mass flow rate of the cold and hot fluids. The velocity of the cold fluid i.e. air varying from $15 \mathrm{~m} / \mathrm{s}$ to $30 \mathrm{~m} / \mathrm{s}$ (with an intermediate step of $20 \mathrm{~m} / \mathrm{s}$ and $25 \mathrm{~m} / \mathrm{s}$ ) whereas the mass flow rate of hot fluid i.e. water is taken as 35lit/hr and 84lit/hr. The logarithmic mean temperature difference (LMTD) method is used to find the heat transfer rate. In thepresent workthe effectiveness and heat transfer rate werecompared between the single and series cross flow heat exchangers. The result shows an average increase of $47.14 \%$ and $59.59 \%$ of heat transfer rate analogous to mass flow rate of 84lit/hrand 35lit/hr.

Keywords: Cross flow Heat exchanger, Effectiveness, Heat transfer rate, Logarithmic mean temperature difference.
\end{abstract}

\section{INTRODUCTION} moves in perpendicular to each other. Cross flow heat exchangers are generally used for heat transfer between gas and liquid for both cooling and heating applications. Mahmoud Khaled, et al [1] determined the overall heat transfer coefficient of a cross flow heat exchanger and found an average relative error of $5 \%$ were observed. Khitam Fuaad Aefan, et al [2] experimentally studied LMTD was selected to determine the heat transfer rate, over all heat transfer coefficient and effectiveness. Karthik Silaipillayarputhur,et al [3] investigated thesteady state sensible performance of multi pass parallel cross flow exchanger, varied capacity rate ratio and ntu.S. D Chavhan, et al [4] compared between elliptical shapeswith staggered tube arrangement and circular staggered tube bank arrangement. Circular tubesproduceseparation, wakes and high-pressure drop. A non- circular tubes offer very low hydraulic resistance and require less pumping power. Chad Randall Harris [5] Studied cross flow micro heat exchanger designed to maximize heat transfer from liquid(water) to gas(air).The cross-flow micro heat exchanger produces a very high heat transfer rate per volume between dissimilar fluids with low fluid pressure drop. Shung wen Kung, et al[6]

Revised Manuscript Received on October 20, 2020.

*Correspondence Author

P. Parabrahma Sai*, Mechanical engineering, Lakireddy Bali reddy college of engineering, Mylavaram. Email: brahmasai9@gmail.com

K. Lakshmi Prasad, Mechanical engineering, Lakireddy Bali reddy college of engineering, Mylavaram. Email: klprasad1108@gmail.com

P. Ravindra Kumar, Mechanical engineering, Lakireddy Bali reddy college of engineering, Mylavaram. Email: pasupuletirk@gmail.com

K. Srinivasa Rao, Mechanical engineering, Lakireddy Bali reddy college of engineering, Mylavaram. Email: srinukarnati123@gmail.com

(C) The Authors. Published by Blue Eyes Intelligence Engineering and Sciences Publication (BEIESP). This is an open access article under the CC BY-NC-ND license (http://creativecommons.org/licenses/by-nc-nd/4.0/)
A cross flow heat exchanger is one in which two fluids

describes the interactive effect between the effectiveness and pressure drop and proved that the average temperature of the hot and cold side flow significantly effects the heat transfer rate and pressure drop at same effectiveness. H.Ingimundardottir, et al[7] Studied detection of fouling in a heat exchanger at perfect steady state conditions. To detect fouling when all inputs(inlet temperature of the fluids as well as the mass flow rates)are simultaneously varying. The mass flow rate can vary in a ratio of $2 \%$ and inlet temperatures can vary $+/-20 \%$. A.S Krishnan, et al [8] comparedconventional staggered flowand double cross flow heat exchangerbetween heat transfer rate and pressure drop at same conditions for the two configurations. This study reveals that the proposed configuration gives a maximum increase of $27 \%$ in heat transfer rate per unit pressure drop.Lubencabezsgomez,et al [9] studied thermal performance of multipass parallel cross flow and counter cross flow heat exchangers. Thermal effectiveness of the multipass cross flow configuration varies differently with the number of tube passes. In counter cross flow configuration, the effectiveness increases. The effectiveness alternates in the case of parallel cross flow arrangement though tending progressively to that of the pure parallel flow. Jiangfeng Guo, et al[10] studied matrix analysis indicated that the total heat load of the heat exchanger matrix.When the total heat transfer area and other conditions remain unchanged, the heat load of the heat exchanger matrix enhances as the distributed coordination between the two vectors of the local heat flux density, local heat transfer area improves, and average coordination angle decreases.X.J. LUO [11] Studied cross flow heat exchanger with external and internal recycles. The results shows the dimensionless heat transfer rate rises with the increase of recycle ratio $\mathrm{R}$ or Capacitance rate ratio $\mathrm{c} 2 / \mathrm{c} 1$ or with the decrease of heat transfer area. The maximum increase of efficiency reached up to $28 \%$ and $21 \%$ for internal and external recycles respectively.Dr.Sadiq Elias Abdullah [12] cross flow heat exchanger with staggered tube bank arrangement studied with four sets of tube banks. Creating a number of $(14,29,59) \mathrm{V}$-groove shaped of one $\mathrm{mm}$ depth on outer surface of three sets while the fourth remain as it is smooth.The heat transfer rate good for smooth tube banks. Meanwhile other sets show that the heat transfer rate increases with increase of Reynolds number and nondimensional pressure drop decreases. Abhishek Bhandegaonkar,et al [13]
Blue Eyes Intelligence Engineering (c) Copyright: All rights reserved. and Sciences Publication

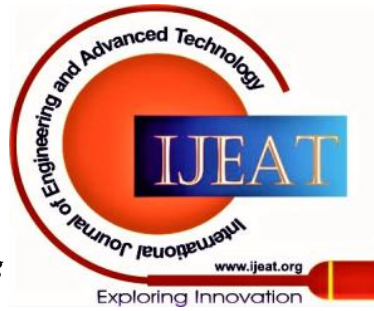




\section{Experimental Study of Heat Transfer Rate in Single and Series Cross Flow Heat Exchanger using Matlab Coding}

Studied thecross-flow heat exchanger with staggered tube bank arrangement with $60^{\circ}$ angle of attack is carried out. In heat exchanger thermal hydraulic performance of tubes was calculated by varying mass flow rate of air and its effect on Nusselt number, Reynolds number, Prandtl number, Convective heat transfer coefficient, and friction factor.

Temperature difference between inlet and outlet of air decreases with increase in velocity of air.Tisha Dixit, et al [14] Heat exchanger performancedefined in terms of hot and cold fluid effectiveness may have different indications. When both the hot and cold fluids were colder than ambient temperature, the hot fluid effectiveness is inversely proportional to heat in-leak while the cold fluid effectiveness shows direct proportionality to the heat increases. When the ambient thermal resistance is extremely low, the cross flow heat exchanger tends to come in equilibrium with surroundings, when the conductance ratio is high, there is a sharp change in cross flow heat exchanger performance.Tianyi Gao, et al [15] Heat exchangers are important facilities that are widely used in data centers, heating, ventilation and air conditioning systems. The effectiveness of heat exchangers strongly influence the thermal performance of cooling systems. Cheensu An, et al [16] studied thermal hydraulic analysis of cross flow finned tube heat exchanger for an outdoor unit in residential airconditioning and heat pump applications. An efficient and accurate heat transfer analysis procedure for a multi row cross flow heat exchanger of an air-conditioning system is the steady state 3-dimensional continuity, momentum and energy equations were solved by using the finite volume method to obtain the thermal-hydraulic characteristics of multi row fin and tube heat exchangers. Toolthaisong, et al [17] studied experimentally the effect of attack angles on airside thermal and pressure drop of the cross flow heat exchangers with staggered tube arrangement. The results shows the heat transfer and pressure drop were increased when the attack of angle and aspect ratio increase.Anwar Sadath, et al [18] The heat exchanger tube was modeled as a cantilever beam with two loose baffles/supports, One at the midspan and one at the end. When the amplitude of tube exceeds a certain value, the tube can impact the baffles. This impact force has been modeled either with a cubic spring or a trilinear spring. W.A khan [19] determined an optimal design of tube banks for both inline and staggered arrangements. The results shows staggered arrangement gives a better performance for lower approach velocities and longer tubes. whereas the inline arrangement performs better for higher approach velocities and larger dimensionless pitch ratios. Compact tube banks perform better for both arrangements and for smaller tube diameters.Mansour Nasirikhalaji, et al [20] the optimization of cross flow heat exchanger having different tubular routers with and without winglets in cylindrical, square and hexagonal geometries.The optimum Reynolds number range between 2900 and 3750 the heat transfer rate is rather high in cylindrical router with winglet. Reynolds number is around 2750 for the case of hexagonal and square with winglets. The entropy generation rate decreases with increasing Reynolds number.

\section{METHODOLOGY}

Published By:

Blue Eyes Intelligence Engineering and Sciences Publication

(C) Copyright: All rights reserved.
The schematic diagram of wind tunnel is shown in fig 1 . It shows the heat exchanger arrangement with wind tunnel.

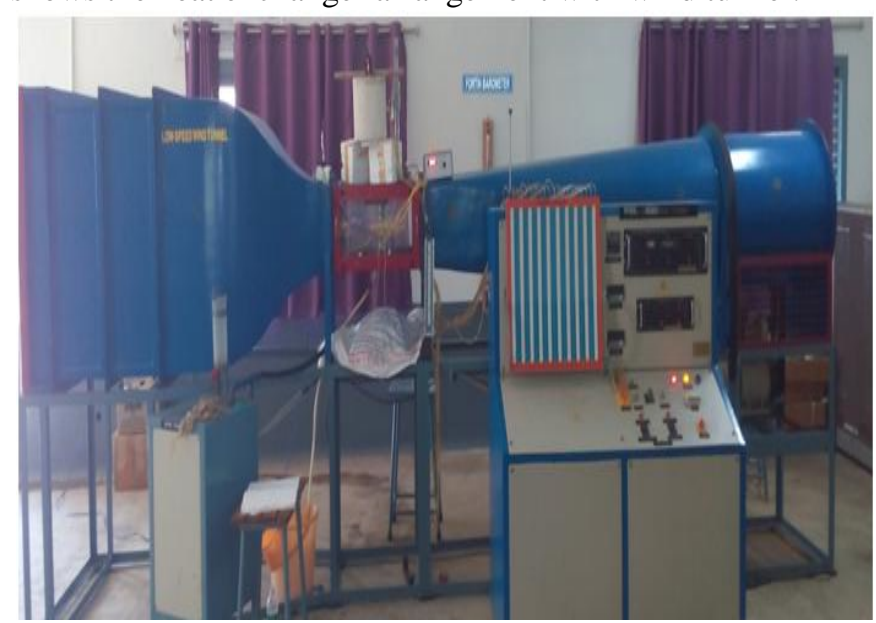

Fig 1 Wind tunnel

Wind tunnels are simply hollow tubes at one end and other end rectangular section. They have power full fans that create a flow of air inside the tunnel. Wind tunnels are used to study the gas flow around a body and the forces generated by the gas body interaction, producing a controlled stream of air in order to study the effects of movement through air or resistance to moving air on models of aircraft and other machines and objects. Mostly air is used in wind tunnel. Wind tunnels have been highly lucrative devices for solving design problems in automobiles, boats, trains,bridges and building structures. Wind tunnel create an air velocity ranging from $5 \mathrm{~m} / \mathrm{s}$ to $30 \mathrm{~m} / \mathrm{s}$.

\section{B. Wind tunnel Specifications}

Type: Low speed wind tunnel

Capacity: $30 \mathrm{~m} / \mathrm{s}$

Max Rpm: 1530

Duty cycle: Continuous

\section{Heat exchanger}

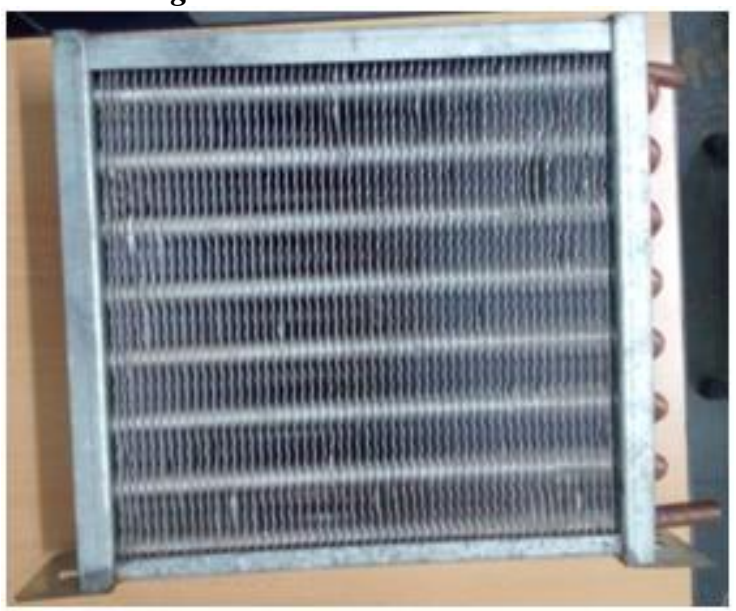

Fig 2 Heat exchanger(Front view)

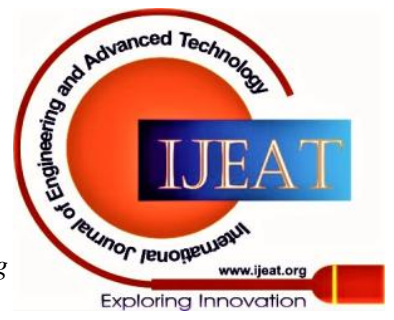




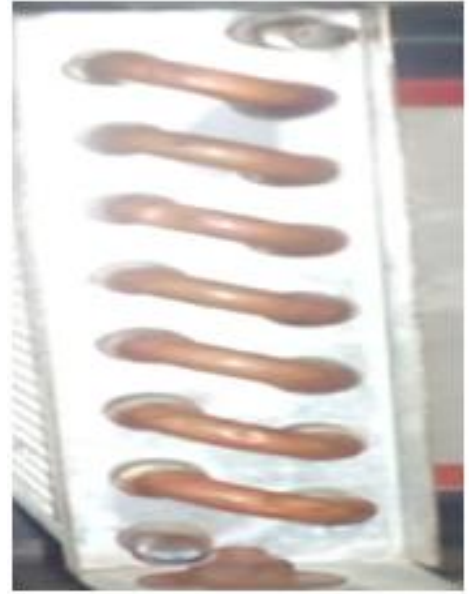

Fig 3 (Side view)

A cross flow heat exchanger is one in which the two fluids moves in perpendicular to each other. In cross flow heat exchangers gas flowing over the tubes and liquid flowing inside the tubes. Cross flow heat exchangers are extensively used in the petroleum, petrochemical, air conditioning, food storage, chemical process, thermal power plant, refrigeration, cryogenic, heat recovery and automobile industries.

\section{Heat exchanger specifications}

\begin{tabular}{|c|c|}
\hline \multicolumn{2}{|c|}{$\begin{array}{c}\text { Heat exchanger } \\
\text { dimensions }\end{array}$} \\
\hline Length & $21 \mathrm{~cm}$ \\
\hline Width & $23 \mathrm{~cm}$ \\
\hline Depth & $4 \mathrm{~cm}$ \\
\hline $\begin{array}{c}\text { Tubes } \\
\text { inner dia }\end{array}$ & $0.76 \mathrm{~cm}$ \\
\hline $\begin{array}{c}\text { Tubes } \\
\text { outer dia } \\
\text { Tube } \\
\text { material }\end{array}$ & $0.98 \mathrm{~cm}$ \\
\hline $\begin{array}{c}\text { Shell/frame } \\
\text { material }\end{array}$ & Aluminum \\
\hline
\end{tabular}

\section{E. Experimental set up with singleheat exchanger}

The experimental set up of cross flow heat exchanger is to investigate the heat transfer rate and effectiveness by varying velocity and mass flow rate of fluids. The schematic diagram of cross flow heat exchanger is shown in below fig 4. It consists of a wind tunnel, Heat exchanger, Temperature indicator, Heater, Insulated container. The wind tunnel is a simply hollow tube at one end and other end at rectangular section, create air flow inside of the tunnel with a fan. Heat exchanger is placed inside of the wind tunnel in cross segment zone perpendicular to air stream inside of the wind tunnel. The hot water flows from insulated container to heat exchanger inlet through channel, Circulated in the tubes entire heat exchanger and flowing out side. Analogous air flowing from one end to other inside of the wind tunnel in perpendicular direction of the water flowing inside of the heat exchanger. Heat transfer takes place from hot water flowing inside of the tubes to air flowing over the tubes. The hot water is coming in to the cold water and cold air is getting hotness. To measure air and water temperatures by using temperature indicator sensors. Hot water circulated in the number of tubes inside the heat exchanger is coming in to cool down by air flowing over the heat exchanger. The water inlet and outlet temperature distinction is more evaluate to air inlet and outlet temperature because of water Circulation and contacting period is more evaluate to air circulating and contacting period is less. Initially experiment is carried at air velocity $15 \mathrm{~m} / \mathrm{s}$ and readings are noted and after the experiment is repeated with different velocities by changing one by one velocity with help of adjustment knob up to $30 \mathrm{~m} / \mathrm{s}$ and readings are noted.

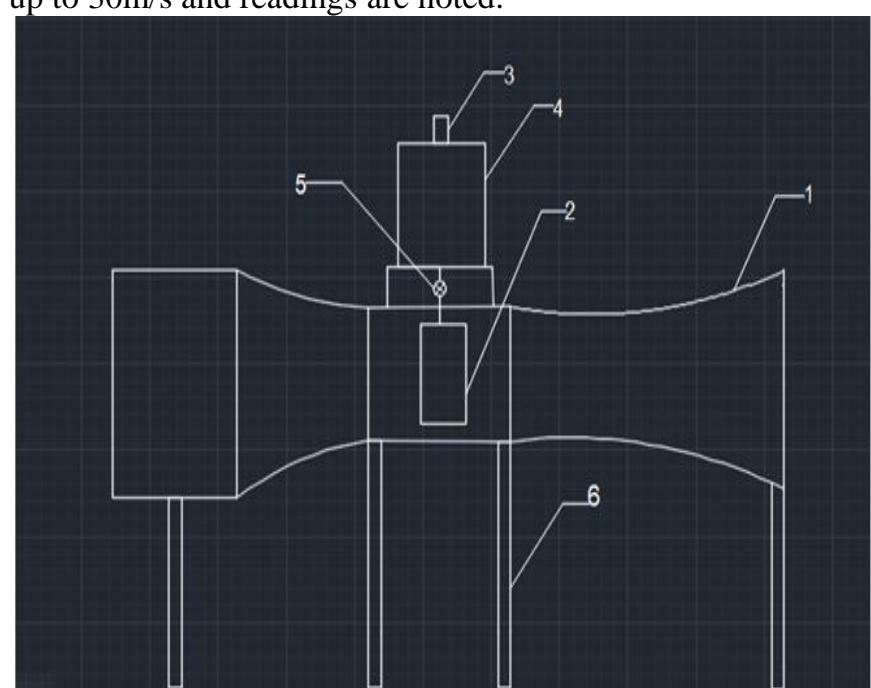

Fig 4 Line diagram of experimental set up

1. Wind tunnel 2. Heat exchanger 3. Heater

4. Insulated container 5. Control valve 6. Stand

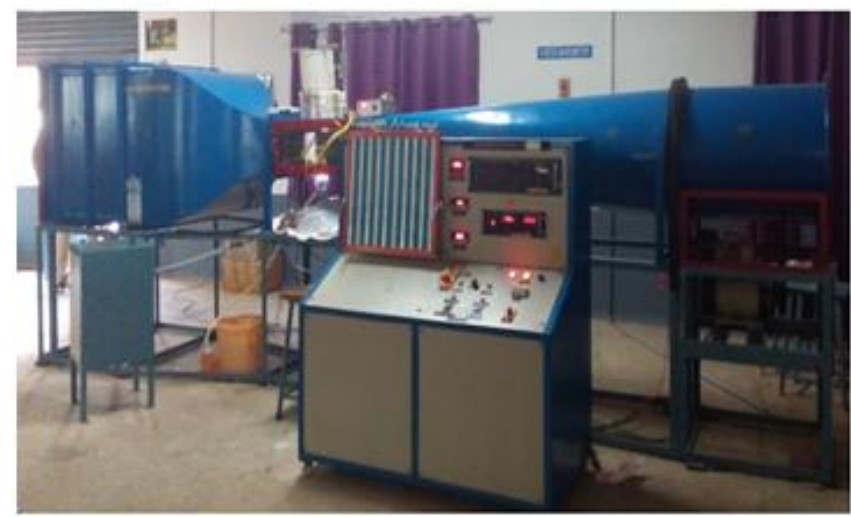

Fig 5 Experimental setup

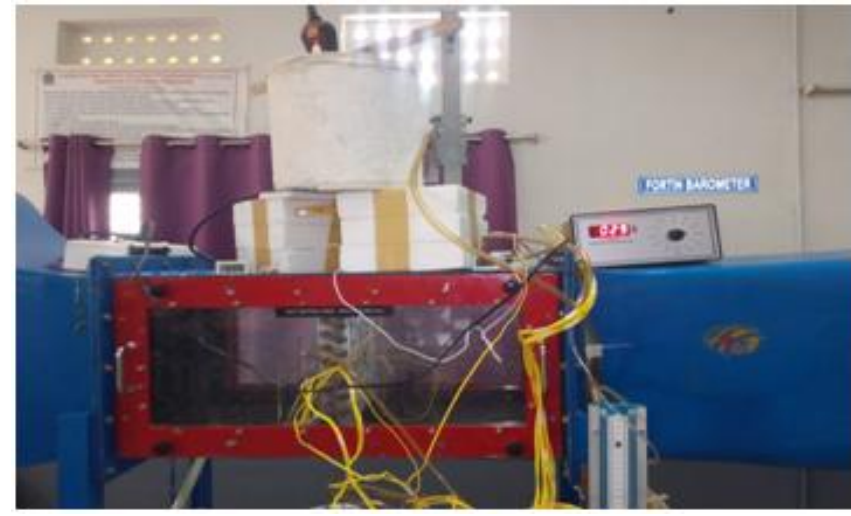

Fig 6 Cross segment zone

Published By:

Blue Eyes Intelligence Engineering and Sciences Publication (c) Copyright: All rights reserved.

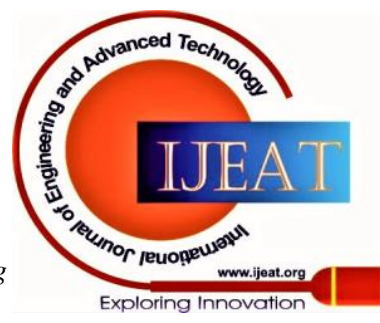




\section{Experimental Study of Heat Transfer Rate in Single and Series Cross Flow Heat Exchanger using Matlab Coding}

\section{F. Experimental set up with series heat exchanger(series connection)}

The schematic diagram of cross flow heat exchanger with series connection is shown in fig 6 . In single heat exchanger we are observed when increase the velocity of air the mass flow rate of air and heat transfer rate increases, at one velocity gives more amount of heat transfer rate, mass flow rate of air and effectiveness. Now again testing with double heat exchanger in series connection examine the heat transfer rate and effectiveness by varying mass flow rate of air and velocity of fluids (air and water) and measure the inlet and outlet temperature of fluids as same as above. Initially experiment carried at air velocity $15 \mathrm{~m} / \mathrm{s}$ with help of a knob on wind tunnel and readings are noted. Then experiment will repeated with different velocities by changing one by one and the readings(inlet and out let temperature of fluids) are noted. Compare to the single heat exchanger with double heat exchanger heat transfer rate, over all heat transfer coefficient, Reynolds number, Nusselt number and effectiveness will increased.

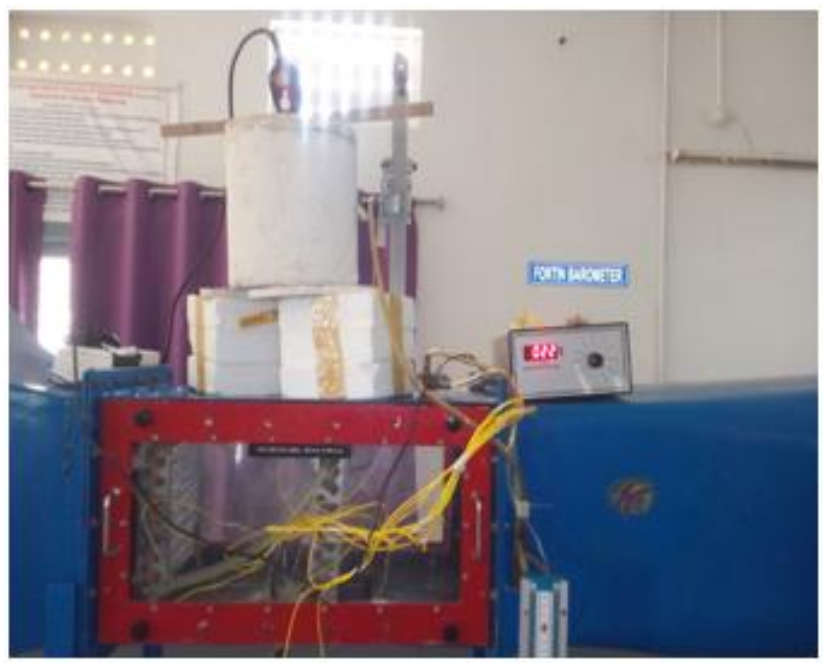

Fig 7 Double heat exchanger (series connection)

\section{MATLAB INTRODUCTION}

The name MATLAB stand for Matrix Laboratory. MATLAB was written originally to provide easy access to matrix software developed by the LINPACK (linear system package) and EISPACK (Eigen system package) projects.

MATLAB is a high performance language for technical computing. It integrates computation, visualization, and it is a modern programming language environment. It has sophisticated data structures, contains built-in editing and debugging tools, and supports object oriented programming. These factors make an excellent tool for teaching and research.

\section{a. MATLAB CODE}

Tin=input('enter inlet temperature of air in k'); Tout=input('enter outlet temperature of air in k'); tin=input('enter inlet temperature of water in k'); tout=input('enter outlet temperature of water in k'); cph=input('enter specific heat of water in $\mathrm{kj} / \mathrm{kgk}$ '); срс=input('enter specific heat of air in kj/kgk');

cf=input('enter correction factor');

$\mathrm{a}=$ input('enter cross sectional area in $\mathrm{m}^{\wedge} 2$ '); rho=input('enter density of water in $\mathrm{kg} / \mathrm{m}^{\wedge} 3$ ');

Rho=input('enter density of air in $\mathrm{kg} / \mathrm{m}^{\wedge} 3$ ');

$\mathrm{v}=$ input('enter velocity of water in $\mathrm{m} / \mathrm{s}$ ');

$\mathrm{V}=$ input('enter velocity of air in $\mathrm{m} / \mathrm{s}$ ');

$\mathrm{di}=$ input('enter value of inner diameter in $\mathrm{m}$ ');

do=input('enter value of outer diameter in $\mathrm{m}$ ');

ri=input('enter value of inner radius in $\mathrm{m}$ ');

ro=input('enter value of outer radius in $\mathrm{m}$ ');

mu=input('enter value dynamic viscosity of water in

$\left.\mathrm{Ns} / \mathrm{m}^{\wedge} 2^{\prime}\right)$;

$\mathrm{Mu}=$ input('enter value dynamic viscosity of air in $\mathrm{Ns} / \mathrm{m}^{\wedge} 2^{\prime}$ );

$\mathrm{kw}=$ input('enter value of water thermal conductivity in

$\left.\mathrm{w} / \mathrm{mk}^{\prime}\right)$;

$\mathrm{ka}=$ input('enter value of air thermal conductivity in w/mk');

$\mathrm{k}=$ input('enter value of material thermal conductivity in

$\left.\mathrm{w} / \mathrm{mk}^{\prime}\right)$;

c=input('enter value of constant');

m=input('enter value of constant two');

cmin=input('enter value of minimum capacity rate in $\mathrm{kj} / \mathrm{k}$ ');

cmax=input('enter value of maximum capacity rate in $\mathrm{kj} / \mathrm{k}$ ');

pr=input('enter value Prandtle number of water');

$\mathrm{Pr}=$ input('enter value Prandtle number of air');

dt2=(tout-Tin);

$\mathrm{dt} 1=$ (tin-Tout);

$\operatorname{lmtd}=((\mathrm{dt} 2-\mathrm{dt} 1) /(\log (\mathrm{dt} 2 / \mathrm{dt} 1)))$;

fprintf('value of \%d\n',lmtd);

re $=(($ rho*v*di $) / \mathrm{mu})$;

$\mathrm{Re}=((\mathrm{Rho} * \mathrm{~V} * \mathrm{do}) / \mathrm{Mu})$;

nua $=\left((\mathrm{c}) *\left(\mathrm{re}^{\wedge} \mathrm{m}\right) *\left(\mathrm{pr}^{\wedge} 0.333\right)\right)$;

fprintf('value of \%dln',nua);

Nuw $=\left((0.023) *\left(\operatorname{Re}^{\wedge} 0.8\right) *(\operatorname{Pr} \wedge 0.4)\right)$;

fprintf('value of \%d\n',Nuw);

hi $=\left(\left(N^{*}{ }^{*} k w\right) /(d i)\right)$;

fprintf('value of \%d $\backslash n$ ',hi);

ho=((nua*ka) $/($ do $))$;

fprintf('value of \%d $\left.\backslash n^{\prime}, h o\right)$;

$\mathrm{U}=(1 /(($ ro/ri $) *(1 / \mathrm{hi}))+((\mathrm{ro} / \mathrm{k}) *(\log (\mathrm{ro} / \mathrm{ri})))+(1 / \mathrm{ho})))$;

fprintf('value of \%d\n',U);

$\mathrm{ntu}=((\mathrm{U} * \mathrm{a}) / \mathrm{cmin})$;

fprintf('value of \%d\n',ntu);

$\mathrm{q}=(\mathrm{cf} * \mathrm{U} * \mathrm{a} * \operatorname{lmtd})$;

fprintf('value of \%d\n',q);

$\mathrm{C}=(\mathrm{cmin} / \mathrm{cmax})$;

$\mathrm{e}=((1 / \mathrm{C}) *(1-\exp (\mathrm{C}-(1-(\exp (-n t u))))))$;

fprintf('value of \%d\n',e);

$\mathrm{Q}=(100: 50: 400)$;

$\mathrm{ma}=(1: 0.5: 4)$;

plot(Q,ma)

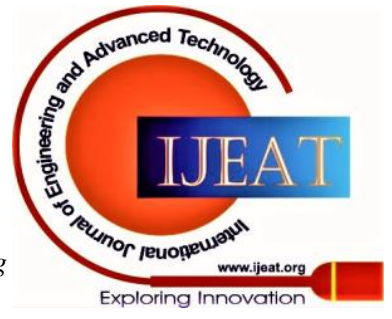




\section{Results and discussion}

4.1Relation between mass flow rate of air (ma)and heat transfer rate $(\mathrm{Q})$ at single heat exchanger

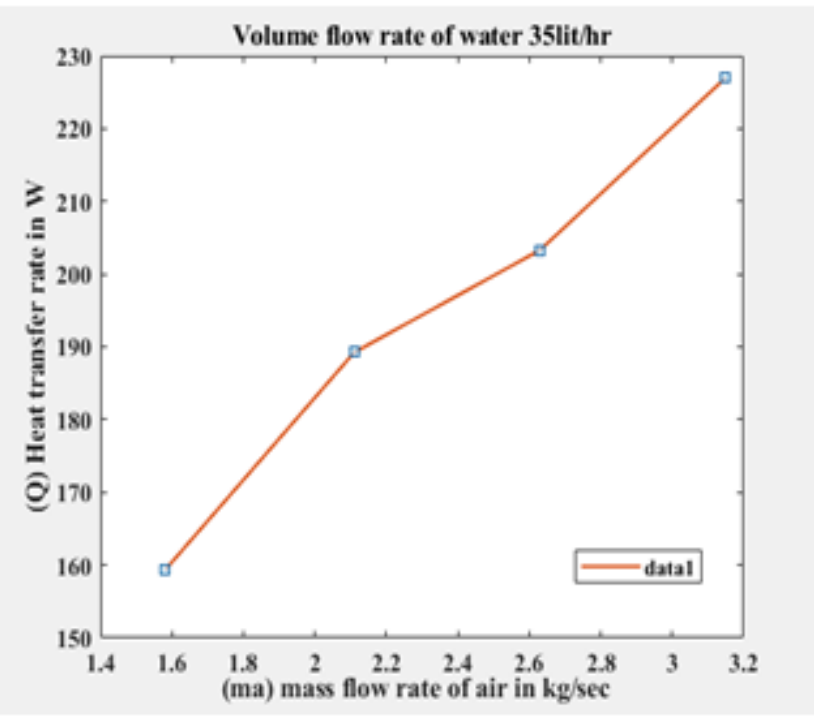

Fig 4.1.1 Graph between ma and $Q$ at volume flow rate of water 35lit/hr

Fig 8 represents the graph betweenm $\mathrm{a}_{\mathrm{a}}$ and $\mathrm{Q}$ at water volume flow rate is 35lit/hr.In this heat transfer rate is directly proportional to mass flow rate of air as a result mass flow rate of air increases corresponding heat transfer rate increases. Because mass flow rate of air, Reynolds number increased when increases the velocity of air. That will increase the amount of air used to be in contact with the heat exchanger surface to reduce the heat. The maximumand minimum amount of heat transfer rate is $227 \mathrm{w}$ and $159 \mathrm{w}$ corresponding air velocity $30 \mathrm{~m} / \mathrm{sec}$ and $15 \mathrm{~m} / \mathrm{sec}$.

4.2 Relation between mass flow rate of air (ma) and heat transfer rate $(\mathrm{Q})$ at single heat exchanger

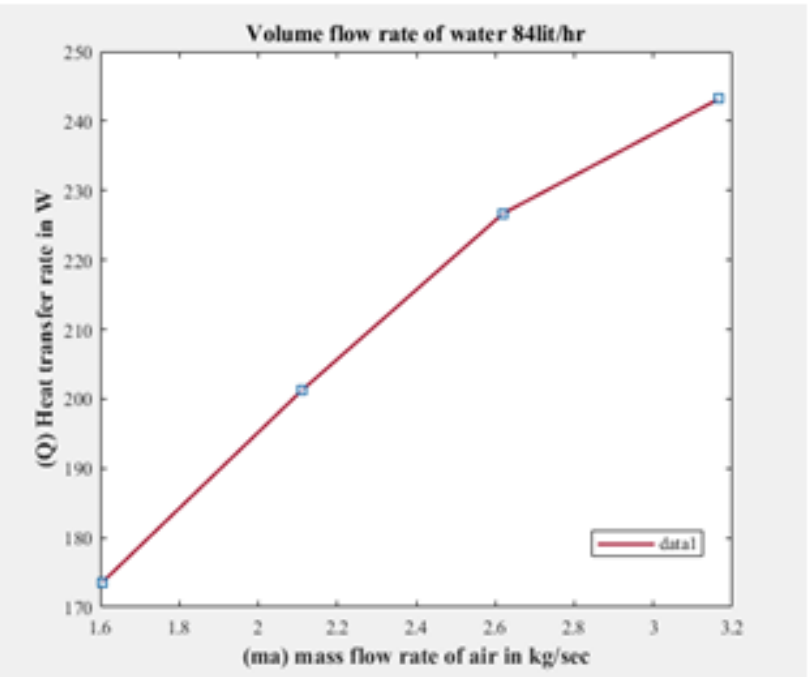

Fig 4.2.1 Graph between ma and $Q$ at volume flow rate of water 84lit/hr

Fig 4.2.1represents the graph between $\mathrm{m}_{\mathrm{a}}$ and $\mathrm{Q}$ at water volume flow rate is 84lit/hr. In this heat transfer rate is depends on the mass flow rate of air, heat transfer rate increases when mass flow rate of air increases and corresponding Reynolds number is also increased. Compare to the fig 8 here the amount of water volume flow rate increased then difference between inlet and outlet temperature of fluids is also increased. The maximum and minimum amount of heat transfer rate is $243 \mathrm{w}$ and $173 \mathrm{w}$ at corresponding air velocities $30 \mathrm{~m} / \mathrm{sec}$ and $15 \mathrm{~m} / \mathrm{sec}$.

4.3 Relation between mass flow rate of air (ma)and heat transfer rate $(\mathrm{Q})$ at series heat exchanger

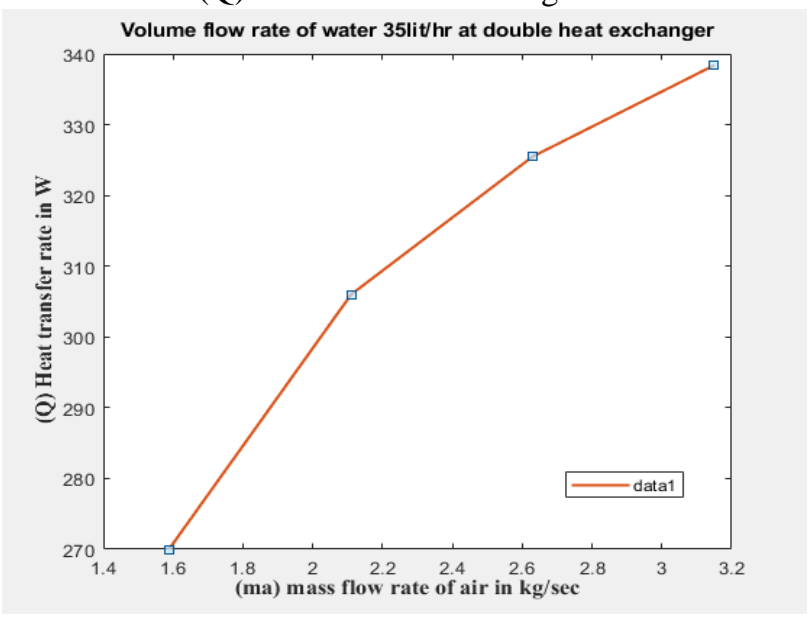

Fig 4.3.1 Graph between ma and $Q$ at volume flow rate of water 35lit/hratseries heat exchanger

Fig 4.3.1signifies the volume flow rate of water is $35 \mathrm{lit} / \mathrm{hr}$ at series heat exchanger in series connection. Heat transfer rate is directly proportional to mass flow rate of air so mass flow rate of air increases corresponding heat transfer rate increases. Because mass flow rate of air, Reynolds number increased when increases the velocity of air, the amount of air used to be contact with the heat exchanger surface to reduce heat. The maximum and minimum amount of heat transfer rate is338w and 270w atseries heat exchanger and in single heat exchanger is $227 \mathrm{w}$ and $159 \mathrm{w}$ atequivalent air velocities $30 \mathrm{~m} / \mathrm{sec}$ and $15 \mathrm{~m} / \mathrm{sec}$. Compare to the series heat exchanger and single heat exchanger at same water volume flow rate,the amount of heat transfer rate increasedis $48.8 \%$ and $69.8 \%$ of heat transfer rate in series heat exchanger analogous air velocities $30 \mathrm{~m} / \mathrm{sec}$ and $15 \mathrm{~m} / \mathrm{sec}$.

1.4 Relation between mass flow rate of air (ma) and heat transfer rate (Q) atdouble heat exchanger(series connection)

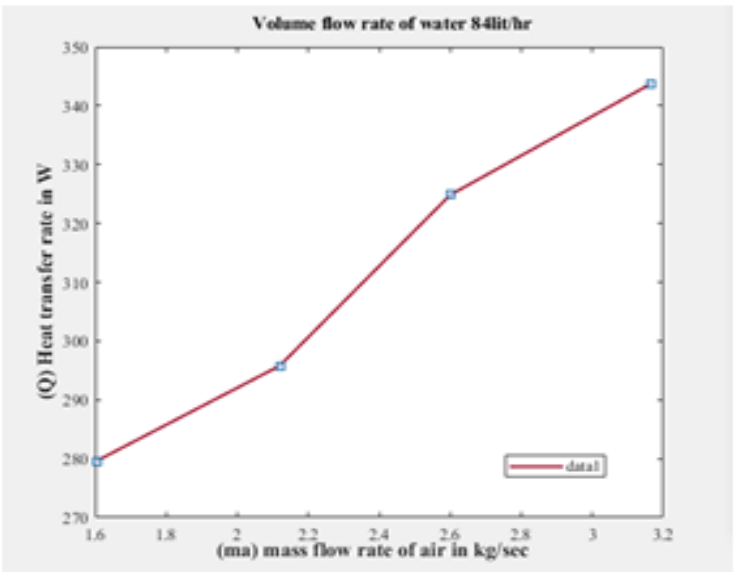

Fig 4.4.1 Graph between ma and $Q$ at volume flow rate of water 84lit/hrat series heat exchanger

Published By:

Blue Eyes Intelligence Engineering

and Sciences Publication

(C) Copyright: All rights reserved.

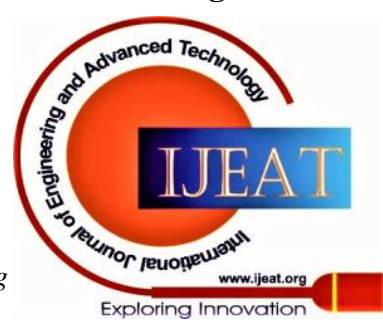




\section{Experimental Study of Heat Transfer Rate in Single and Series Cross Flow Heat Exchanger using Matlab Coding}

Fig 11 denotes the graph between ma and Q at volume flow rate of water is $84 \mathrm{lit} / \mathrm{hr}$ at double heat exchanger in series connection. Mass flow rate of air directly proportional heat transfer rate hence heat transfer rate increases when mass flow rate of air increased. The maximum and minimum amount of heat transfer rate is $343 \mathrm{w}$ and 279 wat series heat exchanger and in single heat exchanger is $243 \mathrm{w}$ and $173 \mathrm{w}$ resultant air velocities $30 \mathrm{~m} / \mathrm{sec}$ and $15 \mathrm{~m} / \mathrm{sec}$. Compare to the single heat exchanger and series heat exchanger the amount of heat transfer rate increases is $41.5 \%$ and $61.27 \%$ inseries heat exchanger at corresponding air velocities $30 \mathrm{~m} / \mathrm{sec}$ and $15 \mathrm{~m} / \mathrm{sec}$.

1.5 Relation between velocity of air and LMTD,NU,H,U at volume flow rate of water 35lit/hr

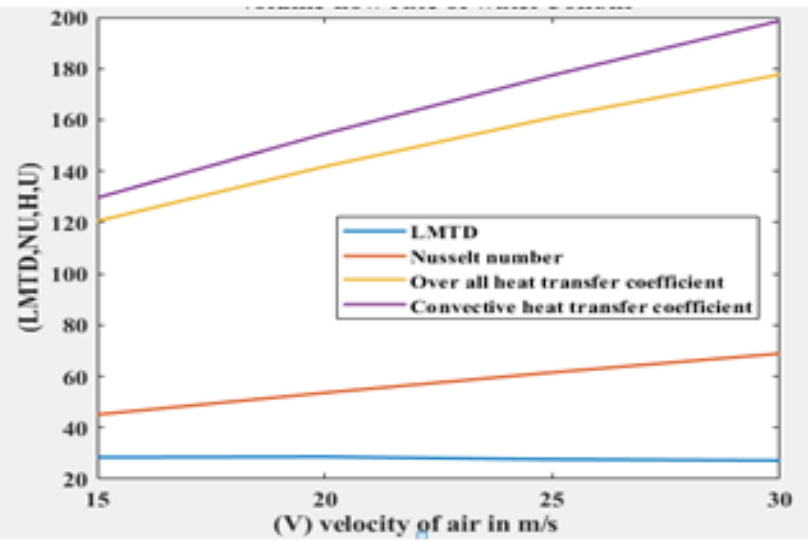

Fig 4.5.1 Variation of velocity of air (Va) with LMTD, Nu, h, U

The above graph indicates the variation of velocity of air (Va) with logarithmic mean temperature difference (LMTD), Nusselt number (Nu), Convective heat transfer coefficient (h), Over all heat transfer coefficient (U) at volume flow rate of water $35 \mathrm{lit} / \mathrm{hr}$. It is observed that the Velocity of air directly proportional to Nusselt number, convective heat transfer coefficient, overall heat transfer coefficient and in-directly proportional to LMTD so velocity of air increases analogous Nusselt number, convective heat transfer coefficient and over all heat transfer coefficientincreases and logarithmic mean temperature difference slightly decreases. The air velocity varies from $15 \mathrm{~m} / \mathrm{sec}$ to $30 \mathrm{~m} / \mathrm{sec}$ when $\mathrm{Nu}, \mathrm{h}$, $\mathrm{U}$ increases heat transfer rate $(\mathrm{Q})$ is also increases.

1.6 Relation between velocity of air (Va) and LMTD, $\mathrm{Nu}, \mathrm{h}, \mathrm{U}$

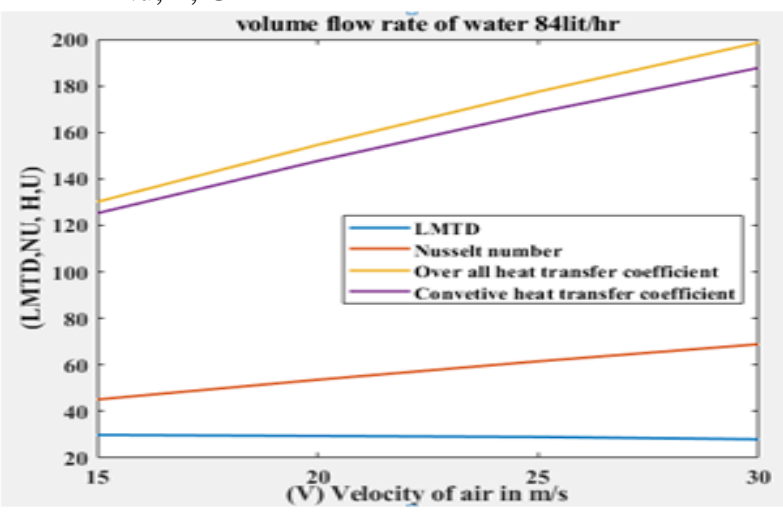

Fig 4.6.1 Variation of velocity of air with LMTD, Nu, h, $\mathbf{U}$

Fig 4.6.1 It shows the variation of velocity air (Va) with logarithmic mean temperature difference (LMTD), Nusselt number $(\mathrm{Nu})$, convective heat transfer coefficient (h), over all heat transfer coefficient (U) at volume flow rate of water $84 \mathrm{lit} / \mathrm{hr}$. It is observed that the velocity of air directly proportional to Nusselt number, convective heat transfer coefficient and over all heat transfer coefficient and incidentally proportional to logarithmic mean temperature difference method so velocity of air increases corresponding $\mathrm{Nu}, \mathrm{h}, \mathrm{U}$ increases and LMTD slightly decreases. Velocity of air varies from $15 \mathrm{~m} / \mathrm{sec}$ to $30 \mathrm{~m} / \mathrm{sec}$ when $\mathrm{Va}$ increases equivalent $\mathrm{Nu}, \mathrm{h}, \mathrm{U}$ increases and heat transfer rate $(\mathrm{Q})$ is also increased.

4.7 Heat transfer rate and mass flow rate of air at different velocities at single and series cross flow heat exchanger.

\begin{tabular}{|l|l|l|c|c|c|}
\hline $\begin{array}{l}\mathrm{S.N} \\
\mathrm{O}\end{array}$ & $\begin{array}{c}\text { Velocit } \\
\mathrm{y} \\
(\mathrm{m} / \mathrm{s})\end{array}$ & $\begin{array}{c}\text { Mass } \\
\text { flow } \\
\text { rate of } \\
\text { air(kg/s } \\
)\end{array}$ & $\begin{array}{c}\text { Heat } \\
\text { transfer } \\
\text { rate }(\mathrm{kw}) \\
\text { at single } \\
\text { heat } \\
\text { exchange } \\
\mathrm{r}\end{array}$ & $\begin{array}{c}\text { Heat } \\
\text { transfer } \\
\text { rate }(\mathrm{kw}) \\
\text { at double } \\
\text { heat } \\
\text { exchange } \\
\mathrm{r}\end{array}$ & $\begin{array}{c}\text { Increased } \\
\text { \% of heat } \\
\text { transferrate } \\
\text { atdoublehe } \\
\text { at } \\
\text { exchanger }\end{array}$ \\
\hline 1. & $15 \mathrm{~m} / \mathrm{s}$ & 1.604 & 173.59 & 279.59 & $61.27 \%$ \\
\hline 2. & $20 \mathrm{~m} / \mathrm{s}$ & 2.11 & 201.20 & 295.40 & $46.76 \%$ \\
\hline 3. & $25 \mathrm{~m} / \mathrm{s}$ & 2.62 & 226.67 & 324.87 & $43.36 \%$ \\
\hline 4. & $30 \mathrm{~m} / \mathrm{s}$ & 3.16 & 243.23 & 343.93 & $41.15 \%$ \\
\hline
\end{tabular}

\section{CONCLUSION}

The cross-flow heat exchangers are used to transfer thermal energy from hot fluid to cold fluid has been studied theoretically and experimentally. Cross flow heat exchangers are generally used for heat transfer between a gas and liquid for both heating and cooling process. The most common examples of cross flow heat exchanger is condenser, radiator and evaporative coil. LMTD(logarithmic mean effective temperature difference) method is used to determine the heat transfer rate, overall heat transfer coefficient and effectiveness. The resultsshow the heat transfer rate increases when the mass flow rate of air increases.

- Flow velocity of the working fluid is effective on the efficiency of heat exchanger.

- Increasing water velocity enhance the heat transfer rate and reduces the irreversibility.

- For heat transfer enhancement increasing heat transfer area, enhancing the turbulence and reducing boundary layer thickness and generating the secondary flow.

- Compare to the single heat exchanger with series heat exchanger at volume flow rate of water $35 \mathrm{lit} / \mathrm{hr}$. Theamount of heat transfer rate increased in series heat exchanger is $69.8 \%$ and $48.8 \%$ at resultant air velocities $15 \mathrm{~m} / \mathrm{s}$ and $30 \mathrm{~m} / \mathrm{s}$.

- Compare to the single heat exchanger with series heat exchanger at volume flow rate of water $84 \mathrm{lit} / \mathrm{hr}$. The amount of heat transfer rate increased is $61.2 \%$ and $41.5 \%$ in series heat exchanger at analogous air velocities $15 \mathrm{~m} / \mathrm{s}$ and $30 \mathrm{~m} / \mathrm{s}$.

Published By:

Blue Eyes Intelligence Engineering and Sciences Publication

(C) Copyright: All rights reserved.

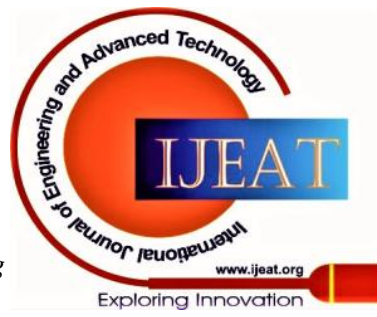


- When we increased velocity of air corresponding mass flow rate of air, Reynolds number, Nusselt number, convective heat transfer coefficient and over all heat transfer coefficient automatically increases.

\section{NOMENCLATURE}

Thi $=$ Temperature of water at inlet in $\mathrm{k}$

Tho $=$ Temperature of water at outlet in $\mathrm{k}$

Tci $=$ Temperature of air at inlet in $\mathrm{k}$

Tco $=$ Temperature of air at outlet in $\mathrm{k}$

LMTD = logarithmic mean temperature difference

$\mathrm{R}=$ Capacity ratio without units

$\varepsilon \quad=$ Effectiveness without units

A $=$ Surface area in $\mathrm{m}^{2}$

$\mathrm{mw}=$ mass flow rate of water in $\mathrm{kg} / \mathrm{sec}$

$\mathrm{ma}=$ mass flow rate of air in $\mathrm{kg} / \mathrm{sec}$

$\mathrm{Va}=$ velocity of air in $\mathrm{m} / \mathrm{sec}$

$\mathrm{Vw}=$ velocity of water in $\mathrm{m} / \mathrm{sec}$

$\mathrm{Re}=$ Reynolds number

$\mathrm{Nu}=$ Nusselt number

$\mathrm{hi}=$ Convective heat transfer coefficient at in side in $\mathrm{w} / \mathrm{m}^{2} \mathrm{k}$

ho $=$ Convective heat transfer coefficient at outside in $\mathrm{w} / \mathrm{m}^{2} \mathrm{k}$

$\mathrm{U}=$ Over all heat transfer coefficient in $\mathrm{w} / \mathrm{m}^{2} \mathrm{k}$

ntu $=$ number of transfer units

$\mathrm{F}=$ Correction factor

$\mathrm{Q}=$ Heat transfer rate in $\mathrm{w}$

$\mu=$ dynamic viscosity in $\mathrm{Ns} / \mathrm{m}^{2}$

$\rho=$ Density in $\mathrm{kg} / \mathrm{m}^{3}$

Cmin = minimum heat capacity

Cmax = maximum heat capacity

$\mathrm{C}$ = capacity ratio

Subscripts

$\mathrm{i}=$ inlet

o $=$ outlet

$\mathrm{a}=$ air

$\mathrm{w}=$ water

$\min =$ minimum

$\max =$ maximum

\section{REFERENCES}

1. Mahoumad Khaled, Mohamad Ramadan, Hicham EI Hage"Innovative approach of determining the overall heat transfer coefficient of heat exchangers" ,Applied Thermal Engineering99(2016) 1086-1092

2. KhitamFuaadAefan, Zainab Hakim Malik, RaadAwad Abdul Hussain, "Design, Fabrication and Testing of Cross Flow Heat Exchnager",Department Of Mechanical Engineering, University of Al-Qadisiyah (2018)

3. Karthik Silaipillayarputhur, Tawfiq AIMughanam,"Performance Charts for Multipass Parallel Cross Flow Heat Exchangers", International Journal of Mechanical Engineering and Robotics Research Vol. 7 (2018)

4. S.D.Chavhan, N.S.Gohel, R.S. Jha, "Thermal Hydraulic Performance Of Elliptical Shape Staggered Tube Cross Flow Heat Exchanger At $45^{\circ}$ Angle of Attack",Inetrnational journal of current engineering and technology(2016) 2347 - 5161.

5. ChadRandall Harris, "Design, Fabrication And Testing of Cross Flow Micro Heat Exchangers", Louisiana State University and Agricultural \& Mechanical College (2001).

6. 6.Shung When Kang, Shin Chau Tseng,"Analysis of Effectiveness and Pressure Drop In Micro Cross Flow Heat Exchanger", Applied Thermal Engineering 27 (2007) 877-885.

7. H. ingimundardottir, S. lalot, "Detection of Fouling In A Cross Flow Heat Exchanger Using Wavelets", Proceding of International Conference on Heat Exchanger Fouling and Cleaning Vlll-2009(peer reviewed).
8. A.s Krishnan and P.Gowtham, "'Computational Study of Staggered and Double Cross Flow Heat Exchanger", Defence Science Journal, vol 67 (2017).

9. Luben Cabezas- Gomez, HelioAparecido Navarro, Jose Maria SaizJabardo, "Thermal Performance of MultipassParallel and Counter Cross Flow Heat Exchanger", Journal of Heat Transfer vol 129 (2007).

10. 10.Jiangfeng Guo, XiulanHuai, "Coordination Analysis of Cross flow Heat Exchnager under High Variations in Thermodynamic Properties", International Journal of Heat and Mass Transfer 113 (2017) 935-942.

11. X.jLuo, "Parametric Study of Heat Transfer Enhancement on Cross Flow Heat Exchangers", Chemical Engineering and Processing (2017).

12. Dr. Sadiq Elias Abdullah, "Investigation the Performance of Cross Flow Heat Exchanger", International Journal of Science and Research, volume 5 Issue 4, (2016).

13. Abhishek Bhandegaonkar, N.S.Gohel, "Experimental Investigation of Cross Flow Heat Exchanger with Staggered Tube Arrangement", International Engineering Research Journal, Special Edition Pgcon Mech-2017

14. Tisha Dixit, Indranil Ghosh, "Two Stream Cross Flow Heat Exchangers in Thermal Communication with The A Surroundings Generalized analysis, International Journal of Heat and Mass Transfer 66 (2013) 1-9.

15. Tianyi Gao, Bahgat G Sammakia, James F. Geer, ”Dynamic Analysis of Cross Flow Heat Exchangers in Data Centers Using Transien Effectiveness Method", IEEE Transactions on Components, and Manufacturing Technology, vol 4 No 12 (2014).

16. CheenSu An, Man-Hoe Kim, "Thermo Hydraulic Analysis of Cross Flow Heat Exchangers", International Journal of Heat and Mass Transfer, 120 (2018) 534-539.

17. S. Toolthaisong, N.Kasayapand, "Effect of Attack Angles on Air Side Thermal and Pressure Drop of the Cross Flow Heat Exchangers With Staggered tube arrangement", Sciverse ScienceDirect Energy Procedia 34 (2013) 417-429

18. Anwar Sadath, Harish N.Dixit, C.P. Vyasaraynai, "Dynamics of Cross Flow Heat Exchanger Tubes with Loose Supports" Journal of Pressure of Vessel Technology, vol 138/051303-1 (2016).

19. W.A Khan, "Optimal design of Tube Banks In Cross Flow Using Entropy Generation Minimization Method", Journal of Thermodynamics and Heat Transfer, vol 21 (2007).

20. Mansour NasiriKhalaji, Isak Kotcioglu, Sinan Caliskan, Ahmet Cansiz, "The Second Law Analysis of Thermodynamics for the Plate Fin Surface Performance in a Cross Flow Heat Exchanger", Journal of Heat Transfer, (2018).

\section{AUTHORS PROFILE}

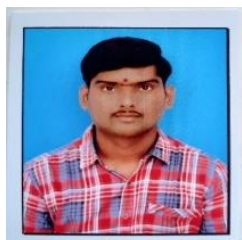

P. ParabrahmaSai, M.Tech (Thermal) student in the Department of mechanical engineering in Lakireddy Bali reddy college of engineering, Mylavaram, A.P.

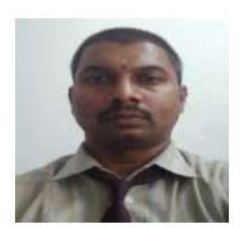

K. Lakshmi Prasad, working as assistant professorin the Department of mechanical engineering in Lakireddy Balireddy college of engineering, Mylavaram.

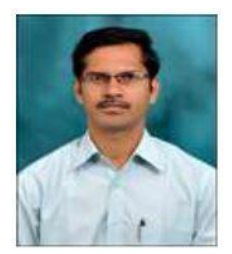

P. Ravindra Kumar, working as professor in the Department of mechanical engineering in Lakireddy Bali reddy college of engineering, Mylavaram.

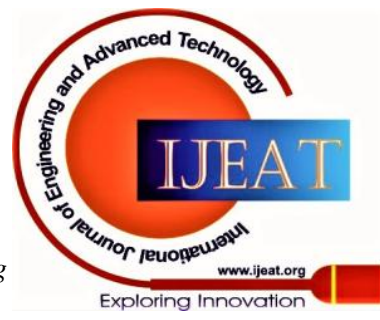


Experimental Study of Heat Transfer Rate in Single and Series Cross Flow Heat Exchanger using Matlab Coding

K. Srinivasa Rao, working as assistant professor in the Department of mechanical engineering in Lakireddy Bali reddy college of engineering Mylavaram.

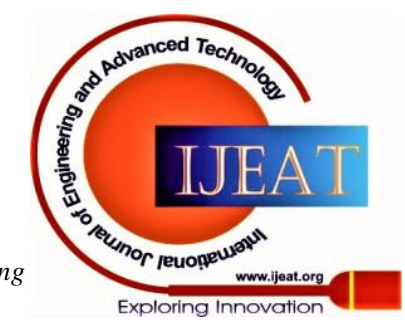

